\title{
The Strategy of Food Safety Handling Policy for Food Street Vendors as a Cultural Product and Culinary Tourism
}

\author{
Rina Rifqie Mariana \\ Department of Industrial Technology \\ Universitas Negeri Malang \\ Semarang, Indonesia
}

\author{
Kun Aniroh Muhrofi-G \\ Diploma IV Tourism Program \\ Universitas Merdeka Malang \\ Malang, Indonesia \\ kun.aniroh@unmer.ac.id
}

\begin{abstract}
The purpose of the study is to describe the existence of street food vendors from the point of view of education, environment, and economical aspect as a cultural product and culinary tourism as the source to publish the policy strategy in handling food street vendors. Methods used in this study is documentary study resulted from the writer's research and literary studies on their social and cultural background, economical and environmental aspects, and interview with the domestic tourist on food street as cultural product and culinary tourism. The findings show that food street vendors' education backgrounds are Elementary and Junior High School graduates so that it influences how they produce the street foods, their investment and income are relatively low, and from the environmental aspect the food street vendors are regarded as persons who disturb public orderliness and the city beauty. On the cultural product and culinary tourism the domestic tourists like to enjoy the creative food which is different from their native towns and are still considering the food price. The findings may be useful in treating street food vendors to produce safe and healthy food by arranging food safety rules for food street vendors so that it will support the development of food as a cultural product and culinary tourism.
\end{abstract}

Keywords - street food, food safety policy, cultural product, culinary tourism

\section{INTRODUCTION}

Small medium enterprise including street food vendor is a potential economy and when it is well developed will solve basic problems in achieving the growth of national economy. The expression of "street foods" describes as an extensive consume foods and beverages sold and sometimes prepared in widespread places, especially streets. Street foods often indicate classic regional civilization and occur in a countless diversity. There is much variety in the basic materials likewise in the production of street food beverages, light meals and food (Winarno and Allain (n.d)) The positive impact of the existence of street food vendors are promising in the sense that a) it can help the tourism growth because their presence is almost in the corner of the city, b) in the sense of investment it is small, but in the number of street food vendor is large, c) in the sense of social economy informal sector has efficient and economical characteristics, d) it has the capability to create investment and it can help increase the growth of economy because the informal sector is a subsystem and the investment which is used comes from their own investment, e) it is easy to create job, f) it is flexible and able to adjust with the fluctuate on of market condition, $g$ ) the relationship between owner and workers is close, i) technology innovation is easy in developing product, j) the food that sells generally local food that has local materials and has high nutrition(Rosyadi, 2000). However it should be admitted that Indonesia has not had the strategy of small medium comprehensive enterprise training that is truly implemented sustainably. Although legally it has been stated in the constitution number 9.year 1995. The constitution of small medium enterprise states government, business and community do the training for small enterprise in the production, process, marketing, human resources and technology.

In relation with production there are some basic problems of the food street vendors as has been shown by Mariana(2012).Generally the problems are a) education, and social culture aspect, in the sense that food street vendors have low education, primary or secondary graduates b) the number of work hours is fluctuate based on the business situation, c) the investment is small so that there will be many new competitors because it does not need special expertise, d) the business can be done by a single person or family (single person- owner-operated enterprises) using traditional management), e)food that they sell does not last long generally made from local materials, f) environment aspect in the sense that city government and some parties regard that the existence of food street vendors disturb general activities of the public, decrease the beauty of the city ,and the environment comfort. It is also regarded illegally because they sell their foods in the places that are not in line with the city vision. The research findings are similar to Moer (2008) of the characteristics food street vendors in Jakarta. The research finding is in line with Moer (2008) on street food vendor characteristic in primary level, that they have migrant status and small investment. So was Sethurahman (1991) in his study in different locations. In the case of street food as a cultural product and culinary tourism food is not merely seen as a means of survival life but 
also a cultural product. Learning food culture is something exciting because when someone is asking about the ingredients, food name, it is actually beyond food learning ( Statjcic, 2013). Food as culinary tourism "Culinary tourism includes any tourism experience in which one learns about, appreciates, and/or consumes food and drink that reflects the local, regional, and national cuisine, heritage, culture, tradition, or culinary techniques." (Culinary Tourism in Ontario: Strategy and Action Plan 2005-2015, p.12).

\section{METHOD}

This study uses documentary and literary studies. The documentaries are based on some Mariana's research on the educationa background, their economical aspects and environmental aspects of the street food vendors. On food as a cultural product and culinary tourism the researcher interviewed 30 domestic tourists on food as a cultural product on the aspect of the name, the ingredients, the choice, the feeling when tasting food and the way how enjoy the food and on culinary tourism on the aspects of the choice of the food, the taste of the food, the price, the food creation and the food safety.

TABLE I. SOCIAL AND EDUCATION BACKGROUND

\begin{tabular}{lllll}
\hline \multicolumn{1}{c}{ Num-ber of SFV } & Education & Investment & Take home pay & \multicolumn{1}{c}{ Env CL } \\
\hline 68/ & PS & $500-1.000$ & $40-50$ & Fair \\
32/ & JH & $1.250-2.000$ & $60-75$ & Fair to Good \\
24/ & SH & $1.500-3.000$ & $80-100$ & Good \\
Total 124 & & & \\
\hline
\end{tabular}

Note:

$$
\begin{array}{ll}
\text { SFV } & \text { : Street Food Vendor } \\
\text { PS } & : \text { Primary School } \\
\text { JH } & \text { : Junior High School } \\
\text { SH } & \text { : Senior High School }
\end{array}
$$

\section{ENV CL: Environment Cleanliness}

\section{RESULT}

The result of the study shows that of 124 street food vendors in Malang city there are 68 Elemantary School graduates, 32 Junior High School graduates, and 24 High School Graduates .This is of course influences the food street food preparation and food products quality. On the aspectof economy it is found that their investment is between IDR 500.000-3.000.000 to IDR and the takehome pay is IDR 40.000-100.000 per day. About the environmental aspect the street food vendors shows that they are classified into 2 Fair and Good. Table I will show the social and education background.
When the domestic tourists are asked about the food as a cultural products mostly $(70-80 \%)$ they want the unique food name name that have not been tasted before, they do not pay attention to the ingredients, they prefer local foods, and they prefer good taste, , and they like to enjoy foods with friends. The $50 \%$ of the respondents do not pay pay attention to the ingredients. On the culinary tourism, they $(70-80 \% \%)$ prefer local food, yummy foods, not expensive foods, creative foods, and do not pay attention much to the safety of the foods. The

\begin{tabular}{|c|c|c|c|c|c|}
\hline No & State-ment & Number & $\begin{array}{c}\text { Yes } \\
\text { Percentage }\end{array}$ & Number & $\begin{array}{c}\text { No } \\
\text { Perrcentage }\end{array}$ \\
\hline 1. & The unique food name & 22 & $73 \%$ & 8 & $27 \%$ \\
\hline 2. & The ingredients & 15 & $50 \%$ & 15 & $50 \%$, \\
\hline 3 & The local food & 25 & $83 \%$ & 5 & $17 \%$ \\
\hline 4 & Enjoy food with friends & 28 & $93 \%$ & 2 & $\& \%$ \\
\hline 5. & The food price & 24 & $80 \%$ & 6 & $20 \%$ \\
\hline 6. & The creative food & 26 & $86 \%$ & 4 & $14 \%$ \\
\hline 7. & Yummy food & 25 & $83 \%$ & 5 & $17 \%$ \\
\hline 7. & The food safety & 14 & $46 \%$ & 16 & $54 \%$ \\
\hline 8. & The food area & 20 & $66 \%$ & 10 & $34 \%$ \\
\hline
\end{tabular}
rest of $54 \%$ pay attention to the food safety and $80 \%$ pay attention to the food price.

TABLE II. FOOD STREET AS CULTURAL PRODUCT AND CULINARY TOURISM 


\section{Low Education Background and Its Relation to the Food Quality}

Due to the education background of street food vendors who are mostly elementary school graduates the street food products do not meet the standard of healthy foods. From the documentary reserach findings(Mariana, 2012) other problems of food that were sold were: 1) the use of borax and rodhamin $\mathrm{B}$ in the school areas. As the examples cilok and tempura use rodhamin and borax and these are the favorite food of the primary school students. So was tomato sauces with special trademark which are usually used as a condiment in cilok, tempura, miebakso and miepangsit positively contain rodhamin .Other foods such as warunglalapan are favorite food of Malang people contained chemistry pollution caused by fried oil that are used many times which of course endanger our health (Mariana, 2014), 2) the food production process starting from storing the materials, producing, distribution process and finally come to customers are not standardized. Sanitation hygiene implementation is very weak and this is one of the causes of high microba pollution in the food that is sold by food street vendors (Mariana; 2014) found that Rodhamine $\mathrm{B}$, metanil yellow were used in food home industry. These two are often used in colouring crackers, snack, sweet, candy and steam fish. The points mentioned are the obstacles of culinary growth in Indonesia.

The activity of the points above are still weak and it is added by the weak condition of food trade in which based on the observation caused by 1) the control in the field is still weak although the regulations have been ready (Mariana; 2014), 2) The spirit of regulation to control informal sector is more on the government activity to develop the project and less on the spirit of developing informal sector in developing economy growth, 3) the low education background has the impact on producing food, 4) and it is followed by the low awareness of consumers in choosing safe and healthy food because they focus more on the low price of the food.

To improve the food quality the activity of preparation, production of foods have to be improved. This can be conducted by adding creativity, aesthetics, tradition and local wisdom of the local food in the are elements of increasing the quality of the taste, product value to attract the purchasing power of the consumers. Others are food infrastructure and proper competitive technology and related collaborative institution such as business climate and regional tourism development (Lazuardi and Mandra in Mari ElkaPangestu, 2015).

Other alternative solutions can be technology and non technology. Technology solution can be in the form of special food aspects and non technology solution can be in the form of public education in order to understand the healthy and safe food. To solve the problems of food street vendors can be regarded as dilematic, in the sense that from the point of view of the government that government publishes the rules of arrangement and assistance to the food street vendors. To solve the problem is a little bit complicated because in one side the approach done by the government is supply side oriented without making approach to street food vendors as demand side (Sethurahman, .1991).
Coordination and planning in developing food street vendors in micro and macro level have not been found, even macro policy is said to be in the side of formal economy than informal economy. This shows that handling food street vendors is quite complicated. To some extent they have to be preserved and to some points their existence has to be developed and does not endanger the health of the society, ruine city planning and conflict with the vision of the region.

\section{Strategy for Food Safety Handling Policy}

Some strategic steps in handling food street vendors based on Mariana's research (2014) are as follows:

a. Conducting the study of the policy and rules which have to be done with the related institution (Department of Trade, Department of Health, Department of Agriculture and The Supervisor Board of Medicine and Food)

b. Arranging the regional rules on food safety

c. Providing special location in the strategic city corner which considers the arrangement, the aesthetics, cleanliness, beauty so that customers feel comfortable

d. Providing the infrastructure in the form of camping site or permanent clean and beautiful building which has the impact on customers trust

e. Providing clean and uncontaminated water water which endanger the safety of the food

f. Writing safety guarantee that the food is without preservative and other nutrition information

g. Budgeting infrastrucuture every month and is already budgeted from regional government

h. Making an effort of many parties such as academician, government, businessmen, culinary community

i. Controlling of the existence of food street vendors on food safety and give the strict sanction for those who break the rules

j. Training for food handlers by collaborating with the university through the program of research, community service activities to increase the skill and knowledge in local food production

k. Evaluating and monitoring the ongoing program whether the program is running or not

\section{Food Street as Cultural Product and Culinary Tourism}

Despite the weaknesses in food safety it is admitted that street food help the people in the offices, children at schools and housewives to have breakfast, lunch, diner, to prepare meals at home, or just for snacking. Without their presence we can get difficulty when we want to eat, because food is very close to human life then it can be related as a part of culture.

Food culture including food street is formed at home, in the society and environment. In a big sense culture can be defined as "social domain that emphasize the practices, discourses, and material expressions, which, over time express the continuities and discontinuities of social meaning of a life held in ommon" 
(Anonim, 2016). Domestic tourists who come from other parts of Malang enjoy local food of Malang. This means that in relation with the practices and materials expressions domestic tourists want to taste something different.

Food has some practices and as acultural product food has some unique properties when it is compared to other objects. The findings show that domestic tourists like to unique name of food, enjoy foods with their friends, in a certain comfort area, so behind foods there other things beyond foods that accompany the practices of foods.

Going beyond foods are among others 1) in the long period of time food production has formed cultures,2)food is the best part of the interaction between culture and nature, different culture group does not look similar because they are carved by the foods they eat, 3)food production processes create topography as much as it forms culture, 4) there has always been a functional benefit in the food area to honesty and investigation, and to schooling from what other cultural groups are eating, 5)many of customs and vacation that pay tribute and confirm a family's identity and cultural legacy center on food(Thanksgiving, Ramadan, Christmas, Birthdays) (Monin and Szczurek, 2014).Therefore when Indonesian celebrate Ramadan or Christmas foods that they serve are very special and when we want to be practical we can buy all special foods or partly from food street vendors and we can cook the rest that we think we are experts in preparing, cooking and serving the foods.

\section{Street Food as Culinary Tourism}

Street food is a part of food or culinary tourism and based on the Ontario Culinary Tourism Alliance (OCTA) "Food tourism is any tourism experience in which one learns about, appreciates, and/or consumes food and drink that reflects the local, regional or national cuisine, heritage and culture. And the best way to experience tourism is through food" (. The International Culinary Tourism Development in 2009 later promoted itself as World Food Travel Association, has identified 12 categories of food tourism experiences :1)cooking schools \& classes, 2)culinary attractions, 3)culinary destinations, 4)culinary events, 5) culinary media, 6) culinary lodging, 7) culinary retail \& grocery, 8) culinary tours, guides, packages and agents, 9) dine \& drink establishments 10)farms, ranches \& farmers" markets, 11)food \& drink clubs,12).food manufacturers (Alberta Culinary Tourism Alliance, 2011).

Based on this theory street food can be categorized in culinary attraction, culinary destination, culinary events and culinary tours. How to make it in a good and impressive culinary tour depends on the creativity of the tour planner. One thing that has to be remembered and paid attention to is that the food should be hygienic, the area meets the requirement of cleanliness as the above mentioned. The training of street food vendors on their weaknesses of and the development of culinary tourism can be developed together as the rise of food tourism is now growing rapidly in many parts of Indonesia and other countries.

\section{CONCLUSION}

Street food is a micro industry but in the number it is large so that it can help achieve the national economy growth. To develop street foods there should be comprehensive solution from related institution because there are still many problems concerning food safety, lack of skill and knowledge of street vendors caused by the low education, and the lack of government seriousness in handling street food vendors.

When the street food is already safe and healthy it can be developed into culinary tourism which will have the impact not only for street food vendors but also the society in general and have the impact on maintaining local food culture and finally it has the big impact on economy.

\section{REFERENCES}

Alberta Culinary Tourism Alliance,( 2011), in Anh Ngoc Vu, 2011 Promotion of food tourism on websites of tourist offices: Cross content analyses of Helsinki, Copenhagen, and Lyon, Retrieved 22 October from http://theseus.fi/bitstream/handle/10024/64631/Anh_Vu_ Ngoc_TOBBA11.pdf?sequence $=1$.

Culinary Tourism In Ontario: Strategy and Action Plan 20052015. (undated). (not attributed). Culture(2016), Retrieved 10 November from http://en.wikipedia.org/wiki/Culture).

Lazuardi, MandradanTriady, Mochammad Sandy, (2013). Lazuardi and Mandra in Mari ElkaPangestu, 2015). PengembanganEkonomiKreatif;

RancanaPengembanganKulinerNasional 2015- 2019, PT Republik Indonesia.

Ontario Culinary Tourism Alliance (OCTA).

Mariana,RinaRifqie.(2012).AnalisisSituasiKeamananPanganu ntukMerumuskanKebijakanOperasionalKeamananPanga npadaMakananJajanan di kota Malang. UniversitasNegeri Malang

Mariana, Rina Rifqie (2014). Kajian Keamanan Panganpada Pedagang Kaki Lima di Kota Malang sebagai Rujukan Pengembangan Kebijakan Daerah. Universitas Negeri Malang.

Moer, Hazel, (2008). Jakarta Informal Sector,Monografi Series. LEKNAS- LIPI

Monin B\& Szczurek, Lauren (2014). Food and culture, Retrieved 22 October from http://psych.stanford.edu/ monin/paper

Rosyadi, (2000).HubunganPeneluaran Pembangunan danPertumbuhanEkonomi.Thesis Program

Statjcic, Nevana (2013).Understanding culture: Food as a means of communictation PL ISSN 0239-8818 Hemisphere No.28, 2013 Retrieved 10 November 2016

Sethurahman, S.V., (1991). The Urban Informal Sector in Developing Contries Employment Poverty and Environment. Geneva ILO

Winarno, FG and Allain, A (n.d). Street foods in developing countries: lessons from Asi. Retrieved 10 November 2016 from

http://www.fao.org/docrep/u3550t/u3550t08.htm\#defining\%2 0street $\% 20$ foods $\% 20$ and $\% 20$ fast $\% 20$ foods 